\title{
Marked Increase in Insulin Sensitivity of Human Fat Cells 1 Hour after Glucose Ingestion
}

\author{
Peter Arner, Jan Bolinder, and Jan Östman, Department of Medicine and \\ Research Center, Huddinge Hospital, Karolinska Institute, S-14186 \\ Huddinge, Sweden
}

\begin{abstract}
A B S TRACT The effect of glucose ingestion on insulin action was investigated in isolated human fat cells. Subcutaneous adipose tissue was obtained from eight normal adult volunteers before and $1 \mathrm{~h}$ after oral intake of $100 \mathrm{~g}$ of glucose. Lipolysis (glycerol release) and specific insulin receptor binding were determined. Insulin binding increased significantly by $20-30 \%$ after glucose ingestion. This was due to an increase in insulin binding affinity, without any change in the receptor number. The concentration of insulin producing halfmaximum inhibition $\left(\mathrm{ED}_{50}\right)$ of basal lipolysis was 50 $\mu \mathrm{U} / \mathrm{ml}$ before and $0.25 \mu \mathrm{U} / \mathrm{ml}$ after glucose ingestion $(P<0.01)$, which represented a 200 -fold difference. As regards isoprenaline-induced lipolysis, the $\mathrm{ED}_{50}$ for insulin inhibition was $30 \mu \mathrm{U} / \mathrm{ml}$ before and $2.5 \mu \mathrm{U} /$ ml after oral glucose $(P<0.01)$, which was a 12 -fold difference. The maximum insulin-induced inhibition of basal and isoprenaline-induced lipolysis were not altered after oral glucose. It is concluded that glucose ingestion is accompanied by a marked increase in insulin sensitivity of human fat cells and this may be an important modulating factor in the overall scheme of insulin action.
\end{abstract}

\section{INTRODUCTION}

The action of insulin on peripheral cells can be regulated by alterations at the receptor and postreceptor levels. Decreases in receptor binding and postreceptor defects have been described in several clinical states of insulin resistance $(1,2)$. These are long-term changes in the regulation of the insulin effect and little is known of the acute adaptation of insulin action on peripheral tissues in man. However, insulin binding to monocytes has been shown to be increased $2-5 \mathrm{~h}$ after glucose ingestion in man, owing to increased receptor affinity (3-5). In rat adipocytes treated with 2-

Address all correspondence to Dr. Arner

Received for publication 23 August 1982 and in revised form 15 November 1982. or 5-h human postglucose serum, the insulin receptor affinity and the insulin sensitivity are enhanced (6). The physiological meaning of these findings is unknown because human target cells have not been studied. The feasibility of investigating rapid changes in insulin action is contigent on access to an easily available target tissue source for serial study. Recently, techniques have been developed for the simultaneous analysis of insulin binding and the antilipolytic effect of insulin in microsamples of human fat, by using mono- ${ }^{125} \mathrm{I}-\left(\mathrm{Tyr}-\mathrm{A}_{14}\right)$-insulin for the binding assay (7) and a bioluminescent technique for the assay of lipolysis (8). These methods were used in this study to investigate the acute effect of glucose ingestion on insulin action in human adipocytes. Subcutaneous adipose tissue was obtained from eight healthy volunteers of normal weight before ingestion of $100 \mathrm{~g}$ of glucose and $1 \mathrm{~h}$ afterwards. A marked increase in insulin action after glucose ingestion is reported.

\section{METHODS}

Subjects. The study group consisted of eight subjects of normal weight (four men and four women) whose ages ranged from 22 to $35 \mathrm{yr}$. The relative weights of the subjects ranged from 95 to $105 \%$, with a mean of $101 \%$. All were healthy and none had a recent history of weight change or intake of any drug known to affect glucose tolerance, insulin release, or adipose tissue metabolism. After informed consent the subjects were investigated in the outpatients department at $8 \mathrm{AM}$ after an overnight fast. The study was approved by the Ethical Committee of the hospital.

Protocol. Subcutaneous adipose tissue $(\sim 0.5 \mathrm{~g})$ from the gluteal region was obtained by surgical biopsy under local anesthesia. Pilocarpin was injected in such a way as not to affect adipose tissue metabolism (9). After the biopsy, 100 $\mathrm{g}$ of glucose was given orally and samples of venous blood were drawn for the determination of plasma glucose (10) and plasma immunoreactive insulin (11) at $0,15,30,45,60$, and $90 \mathrm{~min}$. At $60 \mathrm{~min}$ another fat biopsy was taken. Isolated fat cells were prepared by using Rodbell's method (12).

Lipolysis determination. Isolated fat cells were incubated at a final concentration of $2 \%(\mathrm{vol} / \mathrm{vol})$ in Krebs-Henseleit bicarbonate buffer containing glucose $(2 \mathrm{mg} / \mathrm{ml})$, al- 
bumin (4\%), isopropyl noradrenaline $\left(0\right.$ or $6 \times 10^{-6} \mathrm{~mol} /$ liter), and insulin $(0,0.1,0.25,1,2.5,10,25,100,250$, and $1,000 \mu \mathrm{U} / \mathrm{ml}$ ). Each incubation was run in duplicate at $37^{\circ} \mathrm{C}$ with $\mathrm{O}_{2} / \mathrm{CO}_{2}(95: 5)$ as a gas phase. The total incubation volume was $0.2 \mathrm{ml}$. After incubation, aliquots of the medium were removed for the determination of glycerol, by using a bioluminescent technique that has been described in detail (8). The coefficient of variance for glycerol release in one subject was $6 \%$.

Determination of insulin binding. Isolated fat cells were incubated in duplicate or triplicate at a final cell concentration of $4 \%$ (vol/vol) for $60 \mathrm{~min}$ at $24^{\circ} \mathrm{C}$ in Krebs-Henseleit bicarbonate buffer ( $\mathrm{pH} 7.4$ ) containing albumin $(40 \mathrm{mg} / \mathrm{ml})$, glucose $(2 \mathrm{mg} / \mathrm{ml})$, mono- ${ }^{125} \mathrm{I}-\left(\mathrm{Tyr} \mathrm{A}_{14}\right)$-insulin $(0.05 \mathrm{pmol} /$ $\mathrm{ml}$, and unlabeled insulin $(0-50 \mathrm{pmol} / \mathrm{ml})$. The total incubation volume was $0.4 \mathrm{ml}$. The binding reaction was terminated by adding $2.5 \mathrm{ml}$ of ice-cold saline and rapidly centrifuging the cells through $0.7 \mathrm{ml}$ of silicon oil (13). The supernatant cells were then removed for determination of radioactivity. Nonspecific binding was measured as the amount of ${ }^{125} \mathrm{I}$-insulin remaining in the cell layer in the presence of $20 \mu \mathrm{mol} / \mathrm{ml}$ of unlabeled insulin. All data were corrected for nonspecific binding. Specific tracer binding increased in a linear fashion when fat cells were incubated in concentrations ranging from 1 to $33 \%$ (vol/vol). We have previously shown that, with the use of this method, $(a)$ insulin degradation is negligible, $(b)$ nonspecific binding is low $(\sim 4 \%)$, and $(c)$ a steady state of insulin binding is always reached after $40 \mathrm{~min}$ and maintained for at least $120 \mathrm{~min}$ (14). The coefficient of variance for insulin binding to isolated fat cells was $7 \%$ in one subject.

Fat cell determination. Fat cell size was measured (15), and mean fat cell volume and mean fat cell weight were calculated by previously described methods (16)

Chemicals. Crystalline glucagon-free porcine insulin was kindly supplied by Kabi Vitrum AB, Stockholm, Sweden. Mono- ${ }^{125}$ I-(Tyr $\left.A_{14}\right)$-insulin was obtained from Novo Industri A/S, Bagsvaerd, Denmark, and bovine serum albumin (fraction V) from the Armour Pharmaceutical Co., England.

Expression of the results. Glycerol release and insulin binding were expressed per number of cells. The number of cells incubated was determined by division of the lipid weight of the incubated sample with the mean fat cell weight. Insulin responsiveness was defined as glycerol release in the absence of insulin minus glycerol release at the maximum effective insulin concentration. The dose-response curves for the insulin inhibition of lipolysis were linearized by using a plot of $\log$ insulin concentration vs. $\log (y / 100$ $-y$ ), where $y$ denotes the inhibition of lipolysis at the particular insulin concentration, expressed as a percentage of the maximum effect (17). Half-maximum effect $\left(E_{50}\right)$ was obtained from the point where the line intersects the abscissa at zero. The insulin binding experiments were expressed by competition curves and according to Scatchard's method (18). The reported values represent the mean \pm SEM. Wilcoxon's test and the $\boldsymbol{F}$-distribution test were used for statistical comparison.

\section{RESULTS}

Blood glucose and plasma insulin peaked at $45 \mathrm{~min}$ after glucose ingestion, and the levels were significantly elevated at $60 \mathrm{~min}$ when the second biopsy was taken (Fig. 1). The basal insulin level was $5 \mu \mathrm{U} / \mathrm{ml}$ and the peak level was $\sim 30 \mu \mathrm{U} / \mathrm{ml}$. It has previously

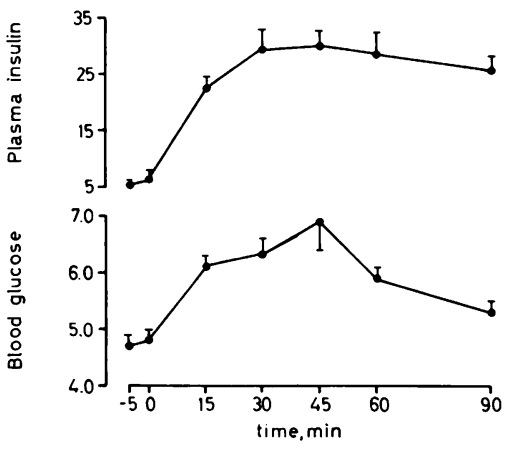

Figure 1 Results of oral glucose load in eight healthy subjects. Plasma insulin $(\mu \mathrm{U} / \mathrm{ml})$ and blood glucose $(\mathrm{mmol} /$ liter $)$ were followed before and during the first $90 \mathrm{~min}$ after ingestion of $100 \mathrm{~g}$ of glucose. Values are mean $\pm \mathrm{SE}$.

been demonstrated that there is a progressive decline in plasma FFA after glucose ingestion (19).

The results of the binding experiments are shown in Fig. 2. At low concentrations of insulin, the binding

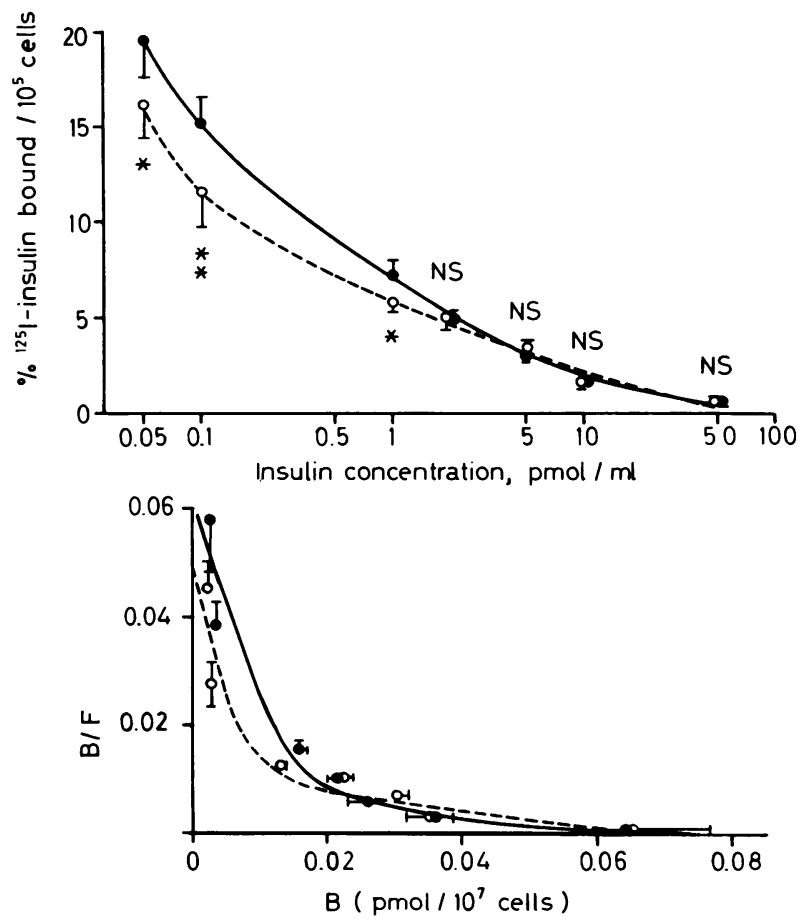

FigURE 2 Effect of oral glucose on insulin binding in eight healthy subjects. Subcutaneous gluteal fat was obtained both before and $60 \mathrm{~min}$ after the oral ingestion of glucose. Isolated fat cells were prepared and specific ${ }^{125} 1$-insulin binding was determined. Data from all subjects were pooled and are presented as a competition-inhibition curve (upper part) and a Scatchard curve (lower part). The statistical evaluation was performed by using Wilcoxon's paired $t$ test. ${ }^{\circ}, P<0.05$; $\because, P<0.010---0$, before oral glucose; $-P$ after oral glucose. $\mathrm{B}$, bound; $\mathrm{B} / \mathrm{F}$, bound /free. 
to fat cells was significantly increased after glucose ingestion; the increase was between 20 and $30 \%$. At insulin concentrations $>1 \mathrm{pmol} / \mathrm{ml}$ the binding was almost identical before and after oral glucose ingestion. These findings indicate that the increase in insulin binding to isolated fat cells $1 \mathrm{~h}$ after glucose ingestion is due not to an enhancement of the receptor number but to an increase in receptor affinity. When the binding data were analyzed by using the Scatchard's method (18) upward concave plots were obtained. This may be due to negative cooperativity interactions or the existence of at least two independent binding sites (1). The Scatchard curves for pre- and postglucose adipocytes crossed the abscissa at the same point. This indicates that maximum binding was the same before and after glucose ingestion $\left(\sim 50 \mathrm{fmol} / 10^{5}\right.$ cells $)$. The difference in the shapes of the two Scatchard curves is consistent with either variations in average receptor affinity or a change in the number of high affinity sites.

The dose-response relationships for the insulin inhibition of basal and isoprenaline-induced glycerol are given in Fig. 3. Before glucose ingestion no inhibition of basal lipolysis was observed at insulin concentrations below $10 \mu \mathrm{U} / \mathrm{ml}$ but a dose-dependent inhibition was seen at higher concentrations; $\mathrm{ED}_{50}$ was $\sim 50 \mu \mathrm{U} / \mathrm{ml}$. After glucose ingestion there was a marked increase in insulin sensitivity as regards the inhibition of basal lipolysis. As little as $0.1 \mu \mathrm{U} / \mathrm{ml}$ was effective and $\mathrm{ED}_{50}$
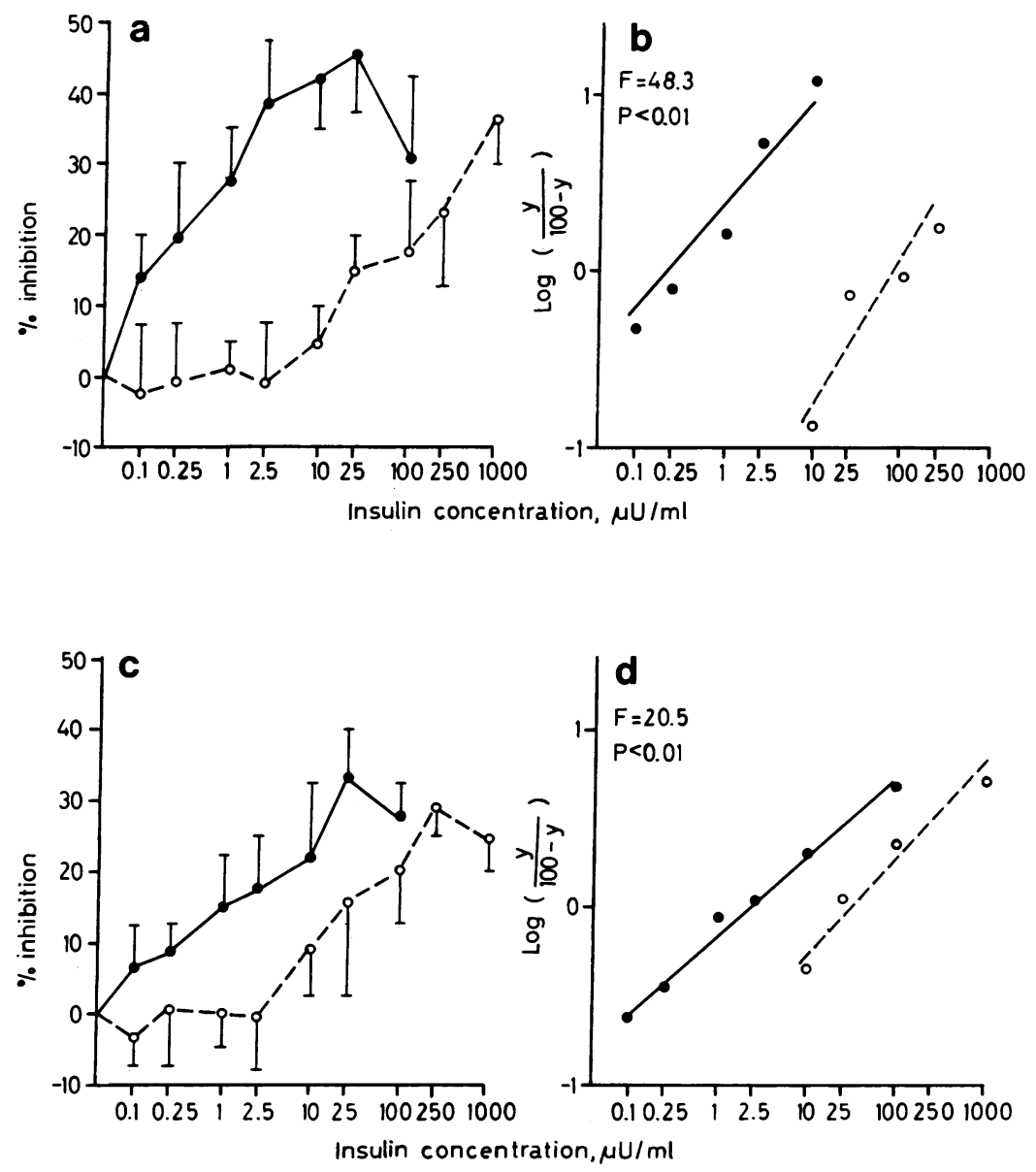

FIGURE 3 Effect of oral glucose on insulin sensitivity in eight healthy subjects. a and $b$, basal lipolysis; $\mathrm{c}$ and $\mathrm{d}$, isoprenaline-induced lipolysis. Isolated fat cells were incubated without (basal) or with $6 \times 10^{-5} \mathrm{~mol} /$ liter of isopropyl noradrenaline (isoprenaline) and various insulin concentrations $(0-1,000 \mu \mathrm{U} / \mathrm{ml})$. Insulin-induced inhibition of basal and isoprenaline-induced rates of glycierol release were determined and expressed as percent inhibition. The dose-response curves were linearized with a log-log plot as described in Methods. The position of the lines was determined by linear regression analysis with the method of least squares. The difference in position between the lines was tested for statistical significance by using the $F$-distribution test. See legends to Figs. 1 and 2 for further details. 
was $\sim 0.25 \mu \mathrm{U} / \mathrm{ml}$; this was a 200 -fold increase in sensitivity as compared with the value before glucose ingestion $(F=48 ; P<0.01)$. The maximum insulininduced inhibition of basal lipolysis was $40 \%$ before and after glucose ingestion. As regards the inhibition of isoprenaline-induced lipolysis, insulin added at concentrations $<10 \mu \mathrm{U} / \mathrm{ml}$ was also ineffective before glucose ingestion; $\mathrm{ED}_{50}$ was $30 \mu \mathrm{U} / \mathrm{ml}$. After glucose ingestion the sensitivity to insulin increased and $\mathrm{ED}_{50}$ was $2.5 \mu \mathrm{U} / \mathrm{ml}$; this was a 12-fold difference as compared with the figure before the administration of oral glucose $(F=21 ; P<0.01)$. The maximum insulin-induced inhibition of isoprenaline-induced lipolysis was similar before and after oral glucose, $30-35 \%$.

Neither the basal nor the isoprenaline-induced rates of glycerol release were altered after oral glucose ingestion; the rate in the presence of isoprenaline was approximately six times more rapid than the basal rate (data not shown). The responsiveness of the antilipolytic effect of insulin also remained unchanged after oral glucose ingestion, both in the basal state and in the presence of isoprenaline (Fig. 4).

The mean fat cell volume was the same before glucose ingestion and $\mathrm{l} \mathrm{h}$ afterwards (data not shown).

\section{DISCUSSION}

Several conditions have been described in which the receptor binding and the metabolic effects of insulin are inhibited $(1,2)$ and the evidence suggests that these changes in insulin action are long-term processes (1). Given the short-term dynamics of insulin production, insulin receptor binding and insulin metabolic effects, it may be suspected that acute regulatory mechanisms

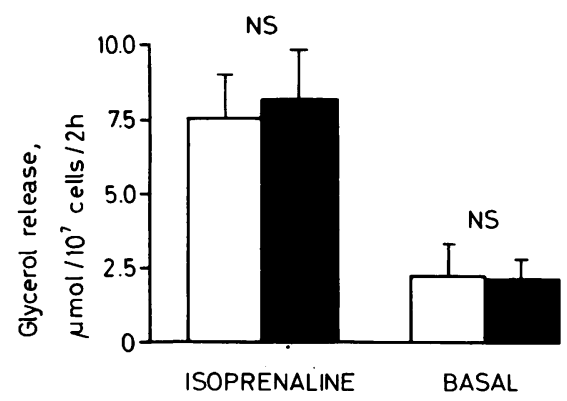

Figure 4 Effect of oral glucose on insulin responsiveness in eight healthy subjects. Insulin responsiveness was calculated from the individual dose-response curves obtained with the experiments presented in Fig. 3 before (open symbols) and after (filled symbols) ingestion of oral glucose. Insulin responsiveness is defined as the rate of glycerol release in the absence of insulin minus the rate at the maximum effective insulin concentration. Basal and isoprenaline-stimulated fat cells were investigated. See legends to Figs. 1-3 for further details. for alterations in insulin action also exist. The present study shows that there is a marked increase in the insulin sensitivity of human fat cells $\mathbf{l ~ h}$ after oral glucose loading and that the enhancement of insulin sensitivity is accompanied by a moderate increase in specific insulin binding to the adipocytes. It has previously been observed in normal adults that insulin binding to circulating monocytes increases $2-5 \mathrm{~h}$ after glucose ingestion (3-5) but is not altered at $1 \mathrm{~h}$ (4). The physiological meaning of these previous findings is unclear, because the circulating levels of insulin and blood glucose generally have declined or returned towards normal between 2 and $5 \mathrm{~h}$ after an oral glucose load. However, we observed an increase in insulin sensitivity and insulin binding at $60 \mathrm{~min}$, when both blood glucose and plasma insulin were almost maximally elevated. Thus, the presently observed increase in insulin sensitivity of human fat cells may play a physiological role. The difference between our study and earlier studies as regards insulin binding may be due to the fact that we investigated a target tissue for insulin action.

We have recently observed that the insulin-receptor interaction in human fat cells is characterized by marked negative cooperativity (20). Therefore, the increase in insulin receptor binding observed in this study after an oral glucose load was probably due to an increase in insulin receptor affinity as judged by the competition and the Scatchard analysis of the binding data. The total binding capacity and the receptor number seemed to be unchanged. These findings concerning affinity and total binding capacity are similar to previous findings concerning the circulating monocytes (3-5). However, in a system with two independent sites, the present binding data can also be explained by a glucose-mediated increase in the number of high affinity insulin receptors.

It is of interest to compare the findings with plasma insulin in Fig. 1 and those with the dose-response relationship of the antilipolytic effect of insulin in Fig. 3 , supposing that such a comparison is valid for the in vivo situation. Before the ingestion of glucose, the minimum insulin concentration effective in depressing lipolysis was $10 \mu \mathrm{U} / \mathrm{ml}$, which meant that the circulating insulin level $(5 \mu \mathrm{U} / \mathrm{ml})$ was below the threshold for inhibiting lipolysis. At $1 \mathrm{~h}$ after the glucose challenge, the plasma insulin level was $\sim 30 \mu \mathrm{U} / \mathrm{ml}$, which was sufficient to maximally inhibit both basal and isoprenaline-induced lipolysis in postglucose adipocytes. Assuming, however, that there was no change in the insulin sensitivity of the latter cells, lipolysis would have been inhibited by $<50 \%$ of the maximum amount in the presence of $30 \mu \mathrm{U} / \mathrm{ml}$ of insulin. Assuming instead that there was no increase in the basal insulin level at $1 \mathrm{~h}$ of $5 \mu \mathrm{U} / \mathrm{ml}$ of insulin, which was ineffec- 
tive on preglucose adipocytes, would cause 75 and $50 \%$ of maximum inhibition of basal and isoprenaline-induced lipolysis, respectively. With the result of these comparisons in mind it is tempting to suppose that a glucose-mediated increase in insulin sensitivity is more important for the antilipolytic effect of the hormone than a glucose-mediated increase in the circulating insulin level.

It has been inferred that changes in insulin receptor binding are accompanied by alterations in insulin sensitivity, whereas changes at postreceptor levels are followed by alterations in insulin responsiveness $(1,21)$. Therefore, the presently observed increase in insulin sensitivity after oral glucose load may be due solely to an increase in receptor binding. The fact that insulin responsiveness was not altered by the glucose load supports this theory. However, the increase in insulin binding was only small $(20-30 \%)$ as compared with the insulin sensitivity, which increased dramatically (12- to 200 -fold). It has recently been observed in rat adipocytes that insulin sensitivity may be altered without any change in insulin binding (22). It is therefore unlikely that the minor alterations in insulin binding would explain the large enhancement of oral glucosemediated increase in insulin sensitivity. Instead, it is probable that alterations at steps close to or beyond insulin binding are more important. We have previously shown that the sensitivity of the antilipolytic effect may depend on the rate of basal lipolysis (17). The glucose-mediated increase in insulin sensitivity could not, however, have been due to changes in basal or isoprenaline-induced lipolysis because these processes were not altered by oral glucose.

It is of interest to note the differences between insulin inhibition of basal and of isoprenaline-induced lipolysis revealed by this study. Before oral glucose the fat cells were sensitive to insulin to about the same extent in the basal state as in the presence of isoprenaline; the $\mathrm{ED}_{50}$ values were $30-50 \mu \mathrm{U} / \mathrm{ml}$. However, the oral glucose load was accompanied by a much more marked shift in insulin sensitivity in the basal state than in the presence of isoprenaline. At $1 \mathrm{~h}$ after an oral glucose load the adipocytes were $\sim 10$ times more sensitive in the basal state than in the presence of isoprenaline, judging by the $\mathrm{ED}_{50}$ values. This indicates that separate mechanisms may be responsible for the insulin inhibition of basal and catecholamine-induced lipolysis.

The mechanism that mediates the acute stimulatory effect of oral glucose on insulin action remains to be determined. It is possible that neuronal signals are activated by the taste of glucose. However, it is more likely that oral glucose stimulates the release of circulatory factor(s). The recent observation (6) that human postglucose serum stimulates the insulin effect on rat adipocytes favors the latter hypothesis. It is unlikely that plasma glucose or insulin are such factors, because Insel and his colleagues (23) have shown that a 3-h infusion of insulin or glucose does not alter insulin receptor binding in man.

We investigated solely the effect of insulin on lipolysis in fat cells and therefore did not determine whether other primary actions of insulin, such as that on glucose transport and other target cells (liver or muscle) also may be altered by oral glucose. For obvious reasons neither muscle nor liver can be used for the present type of experiments in man. Unfortunately, it is also not possible at present to study glucose transport in human fat cells in this respect, because the methods require a large amount of human fat (24). However, it is well recognized that the first step in insulin action is binding to cell surface receptors (25). Thus, it is quite possible that oral glucose stimulates insulin action on other target cells also, so that glucose intake may be of general importance for the shortterm regulation of insulin action in man.

\section{ACKNOWLEDGMENTS}

This study was supported by grants from the Swedish Medical Research Council, Karolinska Institute, The Swedish Medical Association, The Nordic Insulin Foundation, The Swedish Diabetes Association, The Osterman, Hierta, Groschinsky, Tore Nilsson, Folksam Research Foundations, and the Förenade Liv Mutual Group Life Insurance Co.

\section{REFERENCES}

1. Olefsky, J. M. 1981. Insulin resistance and insulin action. An in vitro and in vivo perspective. Diabetes. 30: 148162.

2. Olefsky, J. M., and O. G. Kolterman. 1981. Mechanisms of insulin resistance in obesity and non-insulin-dependent (type II) diabetes. Am. J. Med. 70: 151-168.

3. Muggeo, M., R. S. Bahr, and J. Roth. 1977. Change in affinity of insulin receptors following oral glucose in normal adults. J. Clin. Endocrinol. Metab. 44: 12061209.

4. Bertoli, A., R. DePirro, A. V. Greco, A. Fuscho, L. Spallone, G. Ghirlanda, and R. Lauro. 1980. Response of insulin receptors to oral glucose in normal subjects. $J$. Endocrinol. Invest. 3: 59-61.

5. Moxley, R. T., III, J. N. Livinston, D. H. Lockwood, R. C. Griggs, and R. L. Hill. 1981. Abnormal regulation of monocyte insulin-binding affinity after glucose ingestion in patients with myotonic dystrophy. Proc. Natl. Acad. Sci. USA. 78: 2567-2571.

6. Livingston, J. N., and R. T. Moxley. 1982. Enhancement of adipocyte insulin binding affinity and insulin sensitivity by human serum taken after glucose ingestion. Diabetes. 11: 54a. (Abstr.)

7. Pedersen, O., E. Hjollund, H. Beck-Nielsen, H. O. Lindskog, O. Sonne, and J. Gliemann. 1981. Insulin receptor binding and insulin receptor-mediated insulin degradation in human adipocytes. Diabetologia.: 20: 636-641.

8. Björkhem, I., P. Arner, A. Thore, and J. Östman. 1981. 
Sensitive kinetic bioluminescent assay of glycerol release from human fat cells. J. Lipid Res. 22: 1142-1147.

9. Arner, P., O. Arner, and J. Östman. 1973. The effect of local anaesthetic agents on lipolysis by human adipose tissue. Life Sci. 13: 161-169.

10. Coburn, H. J., and J. J. Carrol. 1973. Improved manual and automated colorimetric determination of serum glucose with use of hexokinase and glucose-6-phosphatedehydrogenase. Clin. Chem. 19: 127-130.

11. Wide, L., R. Axen, and J. Porath. 1967. Radioimmunosorbent assay for proteins. Chemical couplings of antibodies to insoluble dextran. Immunochemistry. 4: 381386.

12. Rodbell, M. 1964. Metabolism of isolated fat cells. I. Effects of hormones on glucose metabolism and lipolysis. J. Biol. Chem. 239: 375-380.

13. Gliemann, J., and O. Sonne. 1978. Binding and receptormediated degradation of insulin in adipocytes. J. Biol. Chem. 253: 7857-7863.

14. Bolinder, J., P. Arner, and J. Östman. 1982. Post-receptor defects causing insulin resistance in normoinsulinemic non-insulin-dependent diabetes mellitus. Diabetes. 31: 911-918.

15. Sjöström, L., P. Björntorp, and J. Vrana. 1971. Microscopic fat-cell size measurements of frozen-cut adipose tissue in comparison with automatic determinations of osmium-fixed fat cells. J. Lipid Res. 12: 521-530.

16. Hirsch, J., and E. Gallian. 1968. Methods for the determinations of adipose cell size and cell number in man and animals. J. Lipid Res. 9: 110-119.
17. Arner, P., J. Bolinder, P. Engfeldt, and J. Östman. 1981. The antilipolytic effect of insulin in human adipose tissue in obesity, diabetes mellitus, hyperinsulinemia and starvation. Metab. Clin. Exp. 30: 753-760.

18. Scatchard, G. 1949. The attraction of proteins for small molecules and ions. Ann. NY Acad. Sci. 51: 660-672.

19. Burns, T. W., C. W. Gehrke, M. J. Angian, and P. E. Langley. 1963. Effect of insulin on plasma free fatty acids of normal subjects. J. Lab. Clin. Med. 62: 646-653.

20. Bolinder, J., L. Kager, J. Östman, and P. Arner. 1983. Differences at the receptor and post-receptor levels between human omental and subcutaneous adipose tissue in the action of insulin on lipolysis. Diabetes. In press.

21. Kahn, C. R. 1978. Insulin resistance, insulin sensitivity and insulin unresponsiveness: a necessary distinction. Metab. Clin. Exp. 27: 1893-1902.

22. Häring, H. U., F. Rinninger, and W. Kemmler. 1981. Decreased insulin sensitivity due to a post-receptor defect as a consequence of ATP-deficiency in fat cells FEBS (Fed. Eur. Biochem. Soc.) Lett. 132: 235-238.

23. Insel, J. R., O. G. Colterman, M. Saekow, and J. M. Olefsky. 1980. Short-term regulation of insulin receptor affinity in man. Diabetes. 29: 132-139.

24. Pedersen, O., and J. Gliemann. 1981. Hexose transport in human adipocytes: factors influencing the response to insulin and kinetics of methyl glucose and glucose transport. Diabetologia. 20: 630-635.

25. Roth, J. 1981. Insulin binding to its receptor: Is the receptor more important than the hormone? Diabetes Care. 4: 27-32. 